\title{
The dawn of two dawns: The mythical, royal and temporal implications of dawn for Psalms 108 and 110
}

\begin{abstract}
Author:
Lodewyk Sutton

Affiliation:

${ }^{1}$ Department of Old

Testament Studies, Faculty of

Theology, University of

Pretoria, South Africa

Research Project Registration: Project Leader: D.J. Human® Project Number: 02364743

\section{Description:}

Dr Lodewyk Sutton is participating in the research project, 'ProPsalms', directed by Prof. Dr Dirk Human, Department Old Testament Studies, Faculty of Theology, University of Pretoria.
\end{abstract}

\section{Corresponding author:}

Lodewyk Sutton,

lodewyksutton@gmail.com

Dates:

Received: 28 Nov. 2016 Accepted: 02 Feb. 2017

Published: 06 Nov. 2017

How to cite this article: Sutton, L., 2017, 'The dawn of two dawns: The mythical, royal and temporal implications of dawn for Psalms 108 and 110', HTS Teologiese Studies/ Theological Studies 73(3), a4463. https://doi. org/10.4102/hts.v73i3.4463

\section{Copyright:}

(c) 2017. The Authors. Licensee: AOSIS. This work is licensed under the Creative Commons Attribution License.

\section{Read online:}

Scan this QR
code with your
smart phone or
mobile device
to read online.

Shachar is identified primarily as a primary noun that is translated as 'dawn' within the Hebrew Bible, yet one must not ignore its mythical dimension. Within the Davidic trilogy Psalms 108110, Shachar takes on an important function, concerning the unity and the message of the trilogy within Book V (Pss 107-150) of the Book of Psalms. A process of restoration (of honour and identity) and hope is announced within Psalm 108 and started within Psalm 110 for Israel after a time of war and exile. This is demonstrated through the mythical, royal and temporal dimensions of Shachar as two dawns within Psalm 108:3 and Psalm 110:3.

\section{Introduction}

Psalm 108-110, as a Davidic trilogy in Book V (Ps 107-150), reflect this notion of war. ${ }^{1}$ The imagery and development of certain words (for example that of feet, footstool, garments, head, right hand, sceptre [staff] and washbasin), and themes in Psalms 108-110 contribute to the understanding of these three psalms as a unity within a context of warfare. ${ }^{2}$ One of these שחר (Shachar), translated as 'dawn' in Psalms 108:3 and 110:3. Within its multiple meanings, Shachar can be understood as a deity (mythical dimension) that influenced or that was associated with the royal houses of the Davidic line (royal dimension) and also indicates a new time or period (temporal dimension). In this article, the question is asked if Shachar in Psalms 108 and 110 demonstrate evidence of one or more of these dimensions and if so how do these dimensions contribute to the interpretation of Psalms 108-110 as a unity? To answer this question, firstly, the mythical dimension of Shachar is evaluated. This is done by formulating an understanding of the deity Shachar and the deity's characteristic trades through an intertextual and extratextual (elucidating to other sources and iconography) analysis of Shachar and to exert these deductions within Psalms 108 and 110. Secondly, the royal and temporal dimensions of Shachar within Psalms 108 and 110 are considered and interpreted. Understanding the mythical, royal and temporal implications of Shachar [dawn] within Psalms 108 and 110 will contribute to their function within the trilogy's role within Book V in the Book of Psalms.

\section{The mythical character of שח (Shachar) within Psalms 108 and 110}

Within the Hebrew Bible, the word שח is used 43 times in a variety of prosaic and poetic texts: 23 times as a noun that is translated with 'dawn', 'tomorrow' and also 'the morning star'; 6 times as an adjective that is translated as 'black'; 14 times as a verb either in the piel translated as 'to seek' or 'to desire' and in the qal translated as 'to become black' or 'to be

1.Both Allen (2002:79-80) and Hossefeld and Zenger (2011:3) understand the trilogy of Psalms 108-110 within the theme of warfare with the purpose of establishing hope, identity and restoration for a Israel as a nation after the Babylonian exile within Book $\mathrm{V}$ of the Book of Psalms.

2.In recent years, the importance to show the relationship between psalms has become increasingly important. These studies have helped to show that a specific psalm should not only be viewed on its own, but also its relationship to a smaller group and also in the bigger groupings. It has already been said that Psalms 108,109 and 110 form part of a smaller Davidic collection in Book $V$ of the Psalms. Most scholars identify these three psalms as a smaller group or Davidic trilogy because of the psalms' introduction formulas Psalms. Most scholars identify these three psalms as a smaller group or Davidic trilogy because of the psalms introduction formulas
that state that the psalms are for or from David (cf. Eybers 1978:32; Gawrisch 1981:8, 16; West 1981:440 footnote 4; Burden et al. 1987:13). Yet most scholars ignore or rather do not take into account the intertextual and extratextual importance and relatedness of 1987:13). Yet most scholars ignore or rather do not take into account the intertextual and extratextual importance and relatedness of
this trilogy. Most interpretations only focus on the individual interpretation of each psalm. For a further discussion on the contributions this trilogy. Most interpretations only focus on the individual interpretation of each psalm. For a further discussion on the contributions
made and the development on the field of canonical critical research, the work of: Howard (1997:1-18); deClaissé-Walford (1997: made and the development on the field of canonical critical research, the work of: Howard (1997:1-18); deClaissé-Walford (1997:
1-14; 2014:1-11); deClaissé-Walford, Jacobson and LaNeel Tanner (2014:21-38); Hossfeld and Zenger (2008; 2011) and Zenger (1998; 2010) can be consulted.

3.Not excluding the extratextual importance that can help to show the intertextual relationship between these texts. A strong relationship can be identified specifically between Psalms 108 and 110. Psalm 110 also shows intertextual references to Psalms 2, 89 and 132 (Hossfeld \& Zenger 2011:144; 152).

Note: This article represents a reworked version of aspects from the PhD dissertation of Lodewyk Sutton, titled, 'A Trilogy of War and Renewed Honour? Psalms 108, 109 and 110 as a Literary Composition', in the Department of Old Testament Studies, University of Pretoria, with Prof. Dr Dirk Human as supervisor. 
intent on'. This indicates that within the etymology of שn in the Hebrew Bible it is primarily used as a primary noun (Ruppert 2004:576). ${ }^{5}$ Part of this language used can be interpreted as a personal noun that is descriptive of the god or goddess Shachar. Therefore, the mythical nature of Shachar is important for this article and also the interpretation of Psalms 108 and 110.

\section{The mythical character of Shachar}

Shachar [proper name] is a deity within the Canaanite mythology in the ancient Near East (Keel \& Uehlinger 1998:208). ${ }^{6}$ Within the Old Testament, the mythological context of Shachar can be seen in Job 3:9, 41:10, Psalms 57:9 (Ps 108:3), 110:3, 139:9, Song of Songs 6:10 and Isaiah 14:12 (Parker 1999:754-755). Within these texts (that can contribute to the understanding of Ps 108 and 110), the following characteristic trades can be recognised:

- Shachar had beautiful eyelids (Job 3:9; 41:10).

- In Psalm 57:9 (also Ps 108:3), Shachar can be awaken from 'her' sleep.

- In Psalm 110:3, Shachar is personified as a female, for the offspring of Shachar's womb is the dew.

- Shachar was seen as a winged god(dess) (Ps 139:9).

- Within Song of Songs 6:10, Shachar is connected with females and the moon.

- Shachar is described as the mother of the Daystar, probably Venus (Isa 14:12).

Foley (1980:186-197) makes the following characteristic observation for Shachar from CTA 23 and the Old Testament texts:

- Part of the twins Shachar [dawn] and Shalim [dusk], and are called the sons of El. (cf. Foley 1980:186; Pfeiffer 1962:34).

- Shachar and Shalim are the divine personification of 'dawn' and 'dusk', they are identical to the goddess Venus that represents the morning and the evening star. They are also compared to Castor and Pollux in classical mythology (cf. Foley 1980:186-197; Pfeiffer 1962:34).

4.A short intertextual analysis indicates that as a primary noun shachar is interpreted mainly as: the crack of dawn (Isa 58:8) that symbolises a new time period; a symbo of hope (Kraus 1986:114); imagery of what is reliable (Hos 6:3); an invading hoard (Joel 2:2); a metaphor for YHWH (Deut 33:2; Isa 60:1-2), mostly descriptive sola language (Smith 1990:31); description of direction and totality, from east to west (Ezek 43:2) (Wiggins 1996:99). Within the Ovid, Metamorphoses XI, 597, the rousing of dawn is also described as the crowing of the cock (Dahood 1986:55).

5.Ruppert (2004:576; cf. Sutton 2011:547) indicates that the etymology of shachar is as follows: 'Heb. šahar is a primary noun. The Akk. šerru(m) II and Assyr. šiāru $(m)$ 'morning' militate against a very 'morning', militate against a verbal derivation, since the substantival form pirás generates only primary nouns, moreover, OSA sahar, 'dawn, daybreak', does no indicate a causative. Forms occuring in Qumran include Middle Heb. šahar (1QH4.6: kšhr, like the dawn', 11QPs 26:11. establishment of the dawn [kwn hiphil]; 4Q487 36,1 Išhr, uncertain); Jewish Aram. sah ${ }^{a} r \bar{a}^{\prime}$, "morning dawn, early morning'; Moab. (fem.!) šhrt; cf. mbq' hšhrt, 'from daybreak'; Ugar. šhr, 'dawn, daybreak', šhr par. $q d m$, 'east wind'; ṣ̌̆r 'Imt, 'from this morning to eternity'; as the twin gods šḥr wšlm, 'morning and evening star', and ' $m$ šḥr wšlm šmmh, 'to šh̆r and šlm in heaven'; Arab. sahar, 'time before daybreak, early morning, dawn'. The ancient Arabic god sahar, 'dawn, daybreak', is portrayed in reliefs with the symbol of the dragonhead. The form šahar also appears as a nomen divinum in personal names, including Ugar. ilšhr, 'šḥr is (my) god'; Phoen. 'bdšhr, šhrb'".

6.The birth of the twins Shachar and Shalim is recorded on the single column tablet CTA 23 (on both sides of the tablet) that was discovered in the excavations at Ras Shamra in 1930 (cf. Pfeiffer 1962:9-18; Gibson 1978:28; Pardee 1997:274). Gibson (1978:125-126) translates this birth tale of the two gods as follows: The two women (became) wives [of El], wives of El even for ever. He stooped (and) kissed their lips; behold! their lips were sweet, sweet as pomegranate[s]. In the kissing (there was) behold! their lips were sweet, sweet as pomegranate $[s]$. In the kissing (there was)
conception, in the embracing (there was) pregnancy; they travailed (and) gave birth conception, in the embraci to Shachar and Shalim.
- Occupied a minor position within the Ugaritic pantheon (Foley 1980:187).

- They have strong astral characteristics (cf. Foley 1980:188189; Pfeiffer 1962:34).

- The gender of the two gods is problematic. Although both names are masculine, Shachar tends to be primarily female, but variety in gender is possible. The birth tale of the two gods also indicates male gender (Meier 1992:1151). The texts of Psalm 110:3 and Song of Songs 6:10 support the female gender (Foley 1980:190).

- Both of the Ugarit gods Shachar and Shalim share and show a strong analogy in the tradition of ancient Israel and the Davidic monarchy. This becomes evident in the names of David's children (Foley 1980:193). This is also, according to Foley (1980:196), the tradition that can be observed within Psalm 110:3 with Shachar that gives birth to the king. The difference with CTA 23 and Psalm 110:3 (and Isa 14:12) is that the described kings are direct offspring of the gods within CTA 23 but only identified with Shachar within Psalm 110:3 and Isaiah 14:12 (Foley 1980:196-197).

- Shachar is identified not only with the king but also with the queen. The reason is that every king that is born is born from a king and a queen, according to Foley (1980:197).

The following characteristics can be added to the above list:

- Rogerson and McKay (1977:44) indicate that a Greek tale about Shachar talks about the goddess sleeping at nights in the ocean bed and that according to the tale had to be awakened by another goddess from her deep sleep. ${ }^{7}$

- A negative characteristic form Shachar derives from the birth tale of Shachar and Shalim. Both the gods as babies thirst or hunger could not be satisfied at the breast of their Mother goddess. It is described as 'one lip to earth, one lip to heaven, the birds of the sky and the fish of the sea entering their mouths' (Meier 1992:1151).

- Another negative characteristic according to Keel and Uehlinger (1998:208) is that the Shachar was also associated with the 'ability to cause disaster and to disturb the overall order of the world'.

\section{The mythical character of Shachar within Psalm 108}

Taking these character trades into account, one can look at Psalms 108 and 110. Psalm 108 is not a mere duplication of Psalms 57 and 60 but a redactional composition that was created with a specific intention. Although Psalm 108 is attributed to David, none of the historical information provided in the superscriptions of Psalms 57 or 60 is used for this new composition. Although, the mythical character of Shachar within Psalm 57:9 is kept within Psalm 108:3. Psalm 57 has a strong use of mythical imagery; already in

7.One can take note of the resemblance to Psalms $57: 9$ and 108:3 when the dawn needs to be awaken. The goddess needs help to be awaken. The sooner the goddess is awake the sooner the psalmist can start to praise or get God's attention cf. Psalm $7: 6$ and $44: 23$. 
verse 2, the imagery of the wings ${ }^{8}$ is notable and in verses 4- $6^{9}$ where the judgment of God can also be compared with Shachar (cf. Anderson 1981:429; Dahood 1968:55; Kraus 1993a:531)

Verses 8-9 reconfirm the petitioners trust in $\mathrm{YHWH}$ and that the crimes of the enemies will destroy them, and YHWH will restore the order of justice that was in disorder. The joyful song that the petitioner is singing, in a way, silences the verbal attack of the enemies. The musical instruments help to churn up a festive melody that awakes the morning sun. The imagery in verse 6 is recalled with God that arises (from his throne). Here the sun rises and with it comes the saving and justice making power of God. Although dawn in this verse reflects more a temporal element, the mythological language must not be ignored (Hossfeld \& Zenger 2005:74-75). Shachar is the goddess that brings new life day after day (Ps 57:9). A comparison with the tomb painting of Ramses X, around the 11th century BCE, within the 'Valley of the Kings' elucidate to this image. Hossfeld and Zenger (2005:73) describe it as: 'The world of heaven and earth. (The heavens, like a roof, rest on the two ends/borders world-mountains.) The space between earth and heaven is 'filled' by the sun disk with scarab [morning sun] and ram-headed figure [daytime or evening sun]. The pharaohs kneeling to the left and the right of the sun offer the regenerative Udjat eye and thus, like the praying and/or praising figures behind them, contribute to the sun's rising and to the development of its life-giving power. In Psalm 57, the petitioner, with his psalm, assumes this function'.$^{10}$ These character trades of Shachar within Psalm 57 is kept for YHWH [saving and justice making power of God]

\footnotetext{
8. In verse 2 , the petitioner feels that he cannot help himself and feels threatened The imagery to come under the shadow of God's wings is an indication that the petitioner seeks help and protection until the danger passes. The wings are like those of a mother bird that protects her infants by sheltering them under her wings and at the same time driving off the enemy with flapping wings. This imagery is especially noted in Egyptian iconography where mostly the king or pharaoh is protected by a winged deity (Hossfeld and Zenger 2005:70-72). This motif is associated with the sun-gods or the sun that is seen as the symbol of strength for deities in Egypt. The sun indicates firstly the life given through light and secondly ( context of the Shachar that is of importance here, is that Shachar [the goddess] had wings, as founded in Psalm 139:9 - כנפי-4
}

9.Verse 6 is the first hymnic refrain, which closes the first stanza (vv. 2-6). The verse is an imperative that is directed to God. The implication of the imperative lies on multiple levels as it calls on YHWH to stop the enemy of the one praying. YHWH is called by the imperative not only to stop the enemy but a request to $\mathrm{YHWH}$ to arise from his throne and to judge the enemy. According to Hossfeld and Zenge (2005:74), the imagery within this Psalm 57 alludes to the battle between YHWH and Chaos (Ps 18:7, 15). The imagery uses the foundations of the earth or the mountains that are at the end of the earth, there where the sun rises and set, at the gates (Ps 65:8). To elucidate to this imagery, a comparison can be made to the Old Akkadian cylindrical seal (around 2200 BCE) where the sun-sod Utu (Akkadian Shamash) is depicted rising between the whe (Akkadian Shamash) is depicted east (Seybold , Mountains of the World in the East and water and wisdom, with his two-faced messenger (Isumu), and on the left presumably the "Lady of Heaven, Inanna, and a divine hero (Gilgamesh?) (Hossfeld and Zenger 2005:269). Keel (1978.22-23) makes the comparison with the Egyptian gates that where arched with lions (Ps 19:4-6). These are opened wide and adorned with lions. According to Keel (1978:25; cf. Sutton 2011:556): 'The edge of the earth is often delineated by lions. It was a dangerous region. In Egypt, however, the lion, like the night, was understood not only as a destructive power (yesterday), but also as a power of rebirth (tomorrow). The above two images help to see how the imagery of the rising sun and that of enemy lions (darkness and destruction) can help to understand the context of Psalm 57 verses 4-6 better. The enemy lions must be destroyed and judged by the rising God from heaven that must come and save the petitioner and the oppressed'.

10.The mythological imagery connected to Shachar is comprised from multiple cultures and does not reflect one specific time period in history. Kruger (1989:263) and Evans $(2015: 21)$ indicate the importance of non-verbal communication (iconography) and that although one study a text in a specific period and political social and historical situation, no text stands on its own. On need to take into account the cross-cultural influences. and the petitioner (prayer function towards YHWH asking for his intervention) within Psalm 108.

\section{The mythical character of Shachar within Psalm 110}

Psalm 110:3 has strong mythological allusions (Bratcher \& Reyburn 1991:950), but present multiple text-critical problems. ${ }^{11}$ An alternative reading according the Masoretic text reads verse 3a's first two words: 'Your nation sacrifices themselves willingly'. This reading does not change the meaning of the text as soldiers in battle are willing to die for their king and country. The LXX'12 and Vulgate reads: 'with you is the power of the prince'. This reading may indicate the possibility of other royalty that battled with the king. This reading cannot be supported in the original translation (De Bruyn 2009:212). Verse 3a (last two words) to $3 \mathrm{c}$ presents text-critical difficulties. The last two words in verse 3 a can alternatively in the Masoretic text be read as 'on the day of your power (or powerfulness)'. היל could be understood as: power, might, army, strength and wealth. Thus some translation translates verse $3 a$ (last two words) as: 'on the day of your power' or 'on the day your army is readied' or 'on the day of your birth' (the last translation is depended on a change of the vowels) (De Bruyn 2009:212).

Verse 3b - בהדררי קדש (- in the Masoretic text reads: 'holy garments'). Some Hebrew texts read הדר as 'mountain'. Verse 3b - מרחם משחר - in the Masoretic text reads: 'out of the לק טל ילדתיף - womb of Shachar' (De Bruyn 2009:212). Verse 3c - in the Masoretic text reads: to you, the dew of your youth'. A Hebrew text alternatively reads 'youth' as 'to give birth'. These readings imply that alternatively verse 3 could read: 'The day that you were born, I have created you from out the womb of Shachar, with the dew on the holy mountains. Then you were clothed with power' The Aramaic Targum translates verse 3 as: 'Your nation Israel sacrifices themselves willingly to the law on the day you go to war. You will join them in the Holiest while the goodwill of YHWH will come over you like the coming of the dew'. These readings vary to a great extent from the original text and cannot be followed. The reason for this is that in this translation the king is presented as the adoptive child of YHWH (De Bruyn 2009:212).

11.Verse 3 is one of the verses that give the most text critical problems in the psalm and it is not the purpose of this article to go into too much detail concerning text critical problems.

12.It has been noted that there are some text critical problems between the Hebrew (rather the Masoretic text) and the LXX versions of Psalm 110 (109), most notably is verse 3 in this regard. Zenger (Hossfeld and Zenger 2011:152) notes that there are scholars that argue that the LXX version of Psalm 110 is an older tradition than the Hebrew text. One of the problems when studying Psalm 110 is that some of the more important textual traditions are not available, preventing a comparative text critical investigation. Steyn (2012:21) observes in this regard that 'there are no extant fragments of it that were found' in the Dead Sea Scrolls and also that this psalm is not in Codex B of the LXX witnesses. In the LXX, the reading does not necessarily differ because of a different textual mode, rather because it can be read as a different vocalisation of the consonants in the Hebrew. Verse 3 in the LXX can be translated as (Hossfeld and Zenger 2011:152): 'With you are magnanimity/rule on the day of (ur power in the glory of the sanctuary/in radiant holiness from the 列 womb before the daystar have loge LXX version (1) cholars feet the LXX verse 3 also translates 'dawn' as 'daystar' (Luke may also have referred to the 'morning star' or 'daystar' in Luke 1:78) or 'morning star'. By translating it as 'daystar', the idea of the birth of the king from the womb of dawn is avoided. 
In the ancient Near East, the king was seen in many of the countries not only as a representative of the god but also becoming a child or descendant of the god, as seen in Egypt with the pharaoh becoming a godly descendant. The royal theology of Israel does not reflect this royal ideology of the ancient Near East. In verse 1, the king becomes a throne companion to $\mathrm{YHWH}$, but not as his physical child. In Israel, the king becomes the adoptive child of YHWH only after his anointing through the goodwill of YHWH (De Bruyn 2009:213; cf. Kraus 1993b:350). According to Kraus (1993b:350), this contributes to the mystery of the relationship between $\mathrm{YHWH}$ and the king. It was a typical image of the ancient Near East to depict the dawn as the mother of the king and relates to the translation of חיל with the birth of someone. It is this mythical character that is kept within Psalm 110:3.

The birth of the god-king in Erment can elucidate to the birth imagery within Psalm 110:3 where the new Pharaoh is born with the scarab (the morning sun or dawn depicted as the Egyptian god Khepri) above his head with wings. ${ }^{13}$ This portrays the birth of a new king, a new time period or the beginning of a new rule. The mythical element of Shachar within Psalm 110:3 stays apparent with the metaphor symbolising a new king and period of rule.

\section{Royal and temporal character of dawn within Psalms 108 and 110}

\section{Psalm 108}

There are several biblical passages in which the deity Shachar is connected with royal individuals (Ps 110:3; Isa 14:12) (Foley 1980:193-197), but one must not ignore Psalm 108. According to Foley (1980:193-197), the 'identification of royal figures with the deified Shachar and Shalim at Ugarit finds an analogy in the tradition of ancient Israel. The Hebrew Bible retains evidence of tradition in which Shachar and Shalim were associated with the Davidic monarchy' ${ }^{14}$ The link between West-Semitic deity Shalim and Jerusalem, the royal city of David, is recognised broadly. Particularly significant is the occurrence of the Shalim element in the names of David's sons (Absalom and Solomon). The theophoric element in the names of two of David's more prominent sons suggests that the god Shalim was associated with Kingship in the Davidic court (other figures that bare this element of Shalim in their name can be seen in Num 34:27; 2 Kgs 15:10, 13-15; 1 Chron $3: 19)$. The occurrence of theophoric Shalim-names in the genealogies of the royal house of Judah suggests that at least at an early phase of the development of Israelite monarchy, there was a tradition which associated the deity Shalim with human sovereignty. The use of such names by non-Davidic

13.Keel (1978:251) describes the image as follows: "Here the woman in labour is shown not enthroned but in realistic kneeling posture. The newborn child is seen coming forth from the womb. The scarab ( $h p r=$ 'to become, to come into being') with the sun indicates that a new "sun" has come into being'.

14.Both Allen (2002:79-80) and Hossfeld and Zenger (2011:3) explain the importance of David within Psalm 108 and 110's process of hope and restoration (royal dimension). Allen (2002:79-80) explains that David represents an eschatological voice of salvation from Israel's enemies. Hossfeld and Zenger (2011:3) see the use of voice of salvation from Israel's enemies. Hossfeld and Zenger (2011:3) see the use of
David as a model of Israel to restore the nation to its former glory, a model according to a Davidic 'foundational era'. royal figures reveals that this tradition was not restricted to a Judean or Jerusalemite provenance'.

The superscription of Psalm 108 with its strong musical influence (vv. 1,2 and 3) as well as its strong military motif of a leader of an army (v. 11) indicates that the speaker of this psalm is a David or rather a king (that is presented in the singular form in this psalm). In verse 7 , the ' $\mathrm{I}$ ' that is represented by the king is the one that prays not for himself but for the rescue of his nation (Allen 1971:393; Hossfeld \& Zenger 2011:117). This was also the role of the petitioner in Psalm 57 in association with Shachar. This usage of the ' $\mathrm{I}$ ' is supported by the strong association between this psalm and Psalm 110, as part of a trilogy. Because of its close relationship with Psalms 109 and 110, it is not likely that this psalm was used within liturgical formula but rather as a poetic imitation of the reception, according to Hossfeld and Zenger (2011:117) of a divine oracle. ${ }^{15}$ It is therefore better to understand Psalm 108 and the trilogy of Psalms 108, 109 and 110 not with a particular individual historical event, but as an expression of the future hope of post-exilic Israel, that is impregnated with royal theology.

Psalm 108:1 uses the more familiar introduction of 'as song' or 'a psalm' as seen in other Davidic psalms (cf. Ps 3-41; 52-71; 72). This confirms a deliberate association with the 'Davidic authority' of Psalm 108 and strengthens the use of Psalm 108 within the trilogy Psalm 108-110. Correspondents in Psalm 108:1 can be seen between the sequences of verbs 'a song' and 'a psalm' and that of the next verse in Psalm 108 with the cohortatives 'I will sing' and 'I will play' (Hossfeld \& Zenger 2011:114-115). In Psalm 108:2, the repetition נכוןלבי in Psalm 57:8 is omitted. The imperative 'awake, my glory' is also replaced with an emphatic particle אף. Therefore, the implication is that the petitioner that addresses himself in Psalm 57:8 has been altered from an accent focused on man to that of a vocative accent focused on God. It is God that is being addressed in Psalm 108:2 (Hossfeld \& Zenger 2011:115). This view of Hossfeld and Zenger is not followed by Botha (2010:576) that suggest that in the corresponding verse to this one in Psalm 57:9, כבודי even more clearly refers to the inner being of the poet, and that this does not affect the occurrence of כבודף in both Psalm 57:6 and Psalm 57:12, negatively. The particle אף אף serves as an expression of addition and emphasis. The particle אף probably establishes a

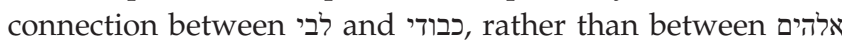
and כבודי. This is a hymnic call to the self to praise God, who is vocatively addressed with three names in Psalm 108 verses 2-5: 'God', 'My Glory' and 'YHWH'. כון in verse 2 could perhaps be better translated with 'ready' than with 'steadfast' (cf. Exod 34:2: 'be ready by morning')? Here, the time also concerns the early morning. The verbs 'sing' and 'sing a psalm' establish a connection to Psalm 101, which describes the function of the king in Jerusalem under the divine rule of YHWH - similar to Psalms 108, 109 and 110 (cf. Botha 2010:586; Hossfeld \& Zenger 2011:119).

15.Dahood (2011:93) is of the opinion that this psalm was compiled for liturgical purposes. 
Psalm 108 verses 1 and 2 is time bounded. The one praying is ready to start praise, and this praise arises from the inner most being of this person. Therefore, the imagery of the heart and also פבוד that can indicate to the 'liver'. The purpose being to indicate that all praise and emotions are directed towards YHWH. Verse 2 comes and explains this urgency through the use of musical instruments and the dawn. ${ }^{16}$ The urgency that this praise and worship towards YHWH must start, therefore the instruments and the dawn need to be awaken as soon as possible, that this process can start (cf. Goldingay 2008:265; Botha 2010:591). Again, the temporal factor of dawn is drawn upon. Wilson (2002:832-833) explains that Psalm 57 verses $7-8$, the awaking of the dawn, is to provide the one who is praying with reassurance and hope that after everything that has happened, there will be a new period of stability. The dawn will bring deliverance, a new period. It is this new time of deliverance that is important for the redactor of Psalm 108 and the trilogy of Psalms 108-110.17 It provides the insurance that in this new time of war, $\mathrm{YHWH}$ will assist (right hand and trampling imagery - Ps 108:7, 14) and bring deliverance (Ps 108:8-12). In verse 3, the harp and lyre should wake the reddish light before dawn, invoking the day of rescue. Daybreak signifies the epiphany of the divine king (God) and the beginning of his activity in the ancient Near-East. It is an enormous occurrence, daily propagating the world-wide glory and power of the divine king (cf. Ps 19:2) (Hossfeld \& Zenger 2011:119). It is this imagery that links Shachar in Psalms 108:3 and 110:3 with one another when the dawn within Psalm 110:3 indicates this daily occurrence of YHWH's assistance and deliverance for the new king. The awaited period in Psalm 108 becomes reality within Psalm 110.

\section{Psalm 110}

Dahood (1970:115-116) understands Psalm 110:3 to be on the 'day of the battle' and focuses primarily on the assistance of YHWH. Mays (1994:352-355) differs in this understanding and interprets it as a 'prophetic text' that places the focus on the new Davidic rule, a new ideal king, as the instrument of YHWH's rule of the entire known world. Both Dahood and Mays interpretations are needed as one need to read Psalm 110 in combination with Psalm 108 as part of a trilogy. Psalm 110:3 becomes then the 'power' or assistance of YHWH as asked in Psalm 108:14. This assistance given to the new king and therefore the imagery develops into an enthronement scene (Hossfeld \& Zenger 2011:149). Terrien (2003:752) emphasises that the language within verse 3 indicates nobility (Job 30:16; Isa 13:2) and royalty. Terrien (2003:752) makes the same conclusion as Hossfeld and Zenger (2011:147) that this is a new king, a new

16.Verses 7-8, within Psalm 57, are a song of trust in YHWH from the one praying. This trust is explained within a twofold declaration. The first declaration makes use of instruments to praise. The second is to awake the 'dawn'. The dawn is a representation of the cycles that take place within creation. A new day that starts, a new beginning (De-Claissé-Walford et al. 2014:490).

17. The metaphor in Psalm 108:2-3 is now applied to the readiness of the awaking dawn, whereas in Psalm 57:8-9 it follows the dire situation of enemies that want to snare him in a net, Psalm 57:7 (Botha 2010:576). Psalm 108:4 replaces 'my Lord' of Psalm 57:10 with YHWH. The first possible explanation for this is the redactional connection made with Psalm 107. In Psalm 107, one of the motifs that structures and shapes the psalm is to 'give thanks to YHWH' (Ps 107:8, 15, 21, 31). A second explanation is that it becomes a link to Psalm 110:1.
David and that he rules with God as the king becomes the adopted child of YHWH (Ps 2:7; Isa 14:12). Hossfeld and Zenger (2011:147-148) describe it as a 'throne companion' as seen in Psalm 110:1. The dawn in Psalm 110:3 indicates a new enthroned king, a new time or age and a new reign (De-Claissé-Walford et al. 2014:836). The dawn imagery within Psalm 110:3 exhibits a strong temporal and royal function.

Psalm 110:3, probably in its original wording of the psalm, showed the enthronement as a procreation or birth of the king (cf. Ps 2:7,18 Isa 9:4). The reading found in the Masoretic text refers to the 'people' of the king and to promises to the king of a gift of incredible renewal from the womb of the dawn. ${ }^{19}$ There are several biblical passages in which the deity Shachar is connected with royal individuals. Psalm 110:3 is one of these. These words are part of an oracle addressed to the Davidic monarch which equates the king's enthronement to his birth as a son of God. YHWH's begetting the king from the womb of Shachar becomes a metaphor for the sovereign's divine election and filiations which became a reality with his enthronement (also Ps 110:1 as throne companion by the sitting on the right hand of God with him on his throne, symbolising a throne community). The tradition in which the Canaanite goddess Shachar gives birth to the king can be discerned behind this image. Isaiah 14:12 provides further evidence of connection between Shachar and kingship. Interesting is that within Psalm 110:3 the king is the son of Shachar (but as already concluded not as YHWH's physical child). In the context of Psalm 110, the temporal element of this metaphor becomes important when the birth becomes a metaphor for a new beginning and period in history. It is apparent that a tradition in which kings were associated closely with the deity Shachar was well known in ancient Israel (taking the text-critical problems with this verse into account with its multiply interpretations and redactions, it is not difficult to see why this could have been possible). It must be acknowledged that the relationship between Shachar and royalty in the Hebrew Bible is not identical to that presented in CTA 23. Nevertheless, Psalm 110:3 and Isaiah 14:12 do support the association of Shachar with kingship (cf. Foley 1980:193-197; Hossfeld \& Zenger 2011:149). ${ }^{20}$

18.Vriezen $(1977: 189,398)$ also makes the connection with the king, between Psalms $110: 3$ and $2: 7$

19.According to Hossfeld and Zenger (2008:195-215), 'youth and dew from the dawn correspond with one another - dew comes at the beginning of the day and youth at the beginning of life. Both these terms refer to fertility. The dew provides the moisture which of life. Both these terms refer to fertility. The dew provides the moisture which the day needs, and the youth of the king brings vitality which the nation need for a flourishing reign. According to Psalm 89:46, the youth of the king is a blessing, and removal of this is a curse (in Ps עלומים 89 עילדות, here In Psalm $10: 3$, the term used for youth is a result of the editors' attempt to change the tex as little as possible, thus the motive of the king as rain, bring life and moisture to his people. The rain imagery can be seen in 2 Samuel 23:4 and Psalm 72:6. The young men have a strong military context: the army is the wonderful gift given by YHWH's vicegerent' (Allen 2002:116). According to Allen (2002:116), the army becomes YHWH's instrument of power and help, it becomes an irresistible force.

20.By reading Psalm 110 in connection with the David-triptych, namely Psalms 108-110, one can link the Song of Deborah (Judg 5:2.9) with the words 'your people (also understanding your people as military personnel) are complete willingness', by doing this, one can refer to the subjugation of the Canaanite kings. Zenger (Hossfeld \& Zenger 2008:195-215) explains that the original wording 'day of your birth' has now become 'day of your might', and that 'power' (lylx;) now becomes the establishing become 'day of your might', and that 'power' (lylx;) now becomes the establishing link to Psalm 108:1 and 4 where it does refer to the military might. The viewpoint of the soldiers of YHWH is shown by the holy clothes (cf. 2 Chron 20:21). It is possible hat the 'holy clothes' were meant to fit the context of the throne scene. The garments become a metaphor for honour, as these clothes indicate a higher status. The double motive of 'morning dew' and 'youth', which metaphorically comments on the vitality and ability of the newly appointed king through the help of YHWH, is shown here in verse 3 (Hossfeld \& Zenger 2011:149). 
In Psalm 108:3, temporal and cosmological connotations can be made from the waking of the dawn. The dawn was seen as a time of help and relief (Botha 2010:576, 579). Psalm 108 and 110 are connected to each other through various motifs and themes. The motif of dawn in Psalm 110:3 as well as in Psalm 108:3 is stated more precisely. In Psalm 110:3, the messianic king is begotten or born from the womb of the dawn. This brings a new interpretation on Psalm 2. Now it is $\mathrm{YHWH}$ himself that wages war against the nations, no longer the human king (Zenger 1998:90). In Psalm 110:3, it has also a directional use (Brown 1998:94). In the end, Psalm 110 is not only a demonstration of YHWH's power and rule but signifies also a time of restoration. In this Psalm, the enemies are stripped of their honour and $\mathrm{YHWH}$ is shown as the true divine king that has the power and honour. In this process also, the king's (and his people) honour is also restored and he receives a status of renewed honour.

\section{Conclusion}

Psalms 108-110 is the dawn of two dawns, where the first dawn awakens the anticipation (Ps 108:3 - mythical awaking of dawn) of a restored nation that is actualised within the second dawn (Ps 110:3) with the creation or rather recreation (birth imagery - mythical birth of a new king) of a new era of hope and restoration for a nation that went through a period of destruction and dishonouring. Wyatt (2001:39) describes the temporal dimension as events that happened in the past. The past events represent the created belief and behaviour for the present. These beliefs and behaviours (created in the past) determine and establish how people live and see the present time. The ones superior rule of a long lost Davidic kingdom reactualise within the imagery of Shachar as a new time period of hope and restoration after the Babylonian exile. Psalms 108-110 do not only present the nation with a future of hope and restoration, it already starts the process of restoration (royal imagery of a new Davidic rule). How is this done? By presenting a literary composition that restores their identity and honour through the imagery of Shachar. In Psalm 108 , this time period of restoration is anticipated; within Psalm 110, this period is started.

\section{Acknowledgements Competing interests}

The author declares that he has no financial or personal relationships which may have inappropriately influenced him in writing this article.

\section{References}

Allen, C.J., 1971, The Broadman Bible Commentary. Volume 4, Ester-Psalms, Broadman Press, Nashville, TN.

Allen, L.C., 2002, 'Psalms 101-150', in W.D. Watts (ed.), Word Biblical Commentary, Thomas Nelson Publishers, Nashville, TN.

Anderson, A.A., 1981, 'Psalms 73-150', in R.E. Clements (ed.), The New Century Bible Commentary, WM. B. Eerdmans Publ. Co, Grand Rapids, MI.

Botha, P.J., 2010, 'Psalm 108 and the quest for closure to the exile', Old Testament Essays 23(3), 574-596.

Bratcher, R.G. \& Reyburn, W.D., 1991, A translator's handbook on the book of Psalms. United Bible Societies, New York.
Brown, W.P., 1998, 'A royal performance: Critical notes on Psalm 110:3ag-b', Journal of Biblical Literature 117(1), 93-96. https://doi.org/10.2307/3266394

Burden, J.J. \& Prinsloo, W.S. (eds.), 1987, Twee-Gesprek met God. Die Literatuur van die Ou Testament. Deel 3, Tafelberg-Uitgewers, Kaapstad.

Dahood, M., 1968, 'Psalms II, 50-100', in W.F. Albright \& D.N. Freedman (eds.), The Anchor Bible, Yale University Press, New Haven.

Dahood, M., 1970, 'Psalms III, 101-150', in W.F. Albright \& D.N. Freedman (eds.), The Anchor Bible, Yale University Press, New Haven, CT.

Dahood, M., 1986, 'Psalm // 51-100', in W.F. Albright \& D.N. Freedman (eds.) The Anchor Bible, Doubleday \& Company Inc., New York.

Dahood, M., 2011, 'Psalms III, 101-150', in W.F. Albright \& D.N. Freedman (eds.), The Anchor Bible, Yale University Press, New Haven, CT.

De Bruyn, J.J., 2009, Die Christologie van die Psalter binne die Konteks van die Koningspsalms? ' $n$ Praktiese Toespitsing op Psalm 45 en 110. Doktorale Tesis, Departement Ou Testament, Universiteit van Pretoria, Pretoria.

deClaissé-Walford, N., 1997, Reading from the beginning. The shaping of the Hebrew Psalter, Mercer University Press, Macon, Georgia.

deClaissé-Walford, N., 2014, 'The Canonical approach to Scripture and the Editing of the Hebrew Psalter', in N. deClaissé-Walford (ed.), The shape and shaping of the Book of Psalms. The Current State of Scholarship. Ancient Israel and its Literature 20, pp. 1-11, Society of Biblical Literature, Atlanta, GA.

deClaissé-Walford, N., Jacobson, R.A. \& LaNeel Tanner, B., 2014, 'The Book of Psalms', in E.J. Young, R.K. Harrison \& R.L. Hubbard (eds.), The New International
Commentary on the Old Testament, William B. Eerdmans Publishing Company, Commentary on the
Grand Rapids, MI.

Evans, A., 2015, 'Two iconographical examples of sun-disc connections', Journal for Semitics 24(1), 20-35.

Eybers, I.H., 1978, Gods Woord in Mensetaal. Deel III. Die Ontstaan, Inhoud en Boodskap van die 'Geskrifte' in die Hebreeuse Kanon, Butterworths, Durban.

Foley, C.M., 1980, The Gracious Gods and the Royal Ideology of Ugarit, PhD Thesis, McMaster University (unpublished), Ontario.

Gawrisch, W.R., 1981, Introduction to the Psalms, viewed 28 March 2014, from http:// www.wlsessays.net/files/GawrischPsalms.pdf

Gibson, J.C.L., 1978, Canaanite Myths and Legends, 2nd edn, T \& T Clark, Edinburgh.

Goldingay, J. 2008, 'Psalms Volume 3: Psalms 90-150', in T. Longman III (ed.), Baker Commentary on the Old Testament Wisdom and Psalms, Baker Academic, Grand Rapids, MI.

Hossfeld, F.L. \& Zenger, E., 2005, 'Psalms 2', in P. Machinist (ed.), Hermeneia, Fortress Press, Minneapolis, MN.

Hossfeld, F.L. \& Zenger, E., 2008, Psalmen 101-150. Herders Theologischer Kommentar zum Alten Testament, Herder, Freiburg, Basel, Wien.

Hossfeld, F.L. \& Zenger, E., 2011, 'Psalm 3', in K. Baltzer (ed.), Hermeneia - A Critical and Historical Commentary on the Bible, Fortress Press, Minneapolis, MN.

Howard, D.M., 1997, The Structure of Psalms 93-100, Eisenbrauns, Winona Lake, IN.

Keel, O., 1978., The symbolism of the Biblical World. Ancient near Eastern iconography and the Book of Psalms, Seabury Press, New York.

Keel, O. \& Uehlinger, C., 1998, Gods, Goddesses, and images of God in Ancient Israel. Fortress Press, Minneapolis, MN.

Kraus, H.-J., 1986, Theology of the Psalms, Augsburg Publishing House, Minneapolis, $\mathrm{MN}$

Kraus, H.-J., 1993a, Psalms 1-59. A Continental Commentary, Fortress Press, Minneapolis, MN

Kraus, H.-J., 1993b, Psalms 60-150. A Continental Commentary, Fortress Press, Minneapolis, MN.

Kruger, P.A., 1989, 'On non-verbal communication in the Baal epic', Journal for Semitics $1(1), 54-69$.

Mays, J.L., 1994, Psalms. Interpretation. A Bible Commentary for Teaching and Preaching, John Knox Press, Louisville, KY

Meier, S.A., 1992, 'Shahar', in D.N. Freedman (ed.), The Anchor Bible Dictionary, vol. 5 (O-Sh), pp. 1150-1151, Doubleday, New York.

Pardee, D., 1997, 'Dawn and Dusk', in W.W. Hallo (ed.), The Context of Scripture, vol. 1 , pp. 274, Brill, Leiden

Parker, S.B., 1999, 'Shahar', in K. Van der Toorn, B. Becking \& P.W. Van der Horst (eds.) Dictionary of Deities and Demons in the Bible, pp. 754-755, Brill, Leiden.

Pfeiffer, C.F., 1962, Ras Shamra and the Bible. Baker Book House, Grand Rapids, MI.

Rogerson, J.W. \& McKay, J.W., 1977, Psalm 51-100, Cambridge University Press, London.

Ruppert, L.F., 2004, 'rx;v šahar', in G.J. Botterweck, H. Ringgren \& H.-J. Fabry (eds.) Theological Dictionary of the Old Testament, p. 576, Willian B. Eerdmans Publishing Company, Grand Rapids, MI.

Seybold, K., 1990, Introducing the Psalms, T \& T Clark, Edinburgh.

Smith, M.S., 1990, 'The near Eastern background of Solar language for Yahweh', Journal of Biblical Literature 109(1), 29-39. https://doi.org/10.2307/3267327

Steyn, G.J., 2012, Paul's Interpretation of Yehoshua ben Yoseph through the Scriptures of Israel as 'Retrodiction', Inaugural Address at the University of Pretoria, 27 August 2012.

Sutton, L., 2011, 'The rising of dawn - An investigation of the spatial and religious background of "dawn" in Psalm 139:7-12', Journal for Semitics 20(2), 546-561. 
Terrien, S., 2003, The Psalms. Strophic Structure and Theological Commentary, William B. Eerdmans Publishing Company, Grand Rapids, MI.

Vriezen, C., 1977, Hoofdlijnen der Theologie van het Oude Testament, H. Veenman en Zonen, Wageningen.

West, J.K., 1981, Introduction to the Old Testament, 2nd edn., Collier Macmillan Publishers, London.

Wiggins, S.A., 1996, 'Yahweh: The God of Sun?', Journal for the Study of the Old Testament 71, 89-106. https://doi.org/10.1177/030908929602107107
Wilson, G.H., 2002, The NIV Application Commentary. Psalms Volume 1, Zondevan, Grand Rapids, Ml.

Wyatt, N., 2001, Space and time in the Religious Life of the Near East, Sheffield Academic Press, Sheffield.

Zenger, E., 1998, 'The composition and theology of the fifth Book of Psalms, Psalms 107-145', Journal for the Study of the Old Testament 80, 77-102. https://doi. org/10.1177/030908929802308005

Zenger, E., 2010, The composition of the Book of Psalms, Uitgeverij Peeters, Leuven. 